\title{
DEVELOPMENT A PROGRAM TO OPTIMIZE DESIGN OF LOW HEAD BUBBLER IRRIGATION
}

\author{
Mohamed A. Rashad*
}

\section{ABSTRACT}

In low head bubbler irrigation, water is applied to the soil surface as a little stream, typically from a small-diameter tube without filtration. The main aim of this study was helped to introduce a proper design of a low head bubbler lateral which achieves full application uniformity. In this study, a computer program was developed to identify bubbler heights $h_{h}$ at each outlet point, maximum of outlet numbers $O_{n}$, lateral length $L_{\max }$ and flow $Q_{T}$, using the data obtained from water temperatures $T_{w}$, bubblers and lateral diameters, allowable lateral upstream pressure head $H_{a l}$ and the soil surface slope. The optimum design example was presented to four bubbler tube diameters of 3.8, 6.0, 10.0 and $13.6 \mathrm{~mm}$ with allowable lateral upstream pressure head $H_{a l}$, of 1.0 and $1.5 \mathrm{~m}$ for different bubbler discharges $q_{b}$. Laboratory experiments to validate this example were performed. The results showed that a high correlation between the developed design program, and the results obtained from laboratory experiments. The study revealed that the program was an efficient and accurate way to design full irrigation uniformity by very low operating pressure.

Key words: Low head irrigation, bubbler heights, design, uniformity, design program.

\section{INTRODUCTION}

$\mathrm{M}$ icroirrigation is the broad classification for frequent, low volume, low-pressure application of water on or beneath the soil surface by drippers, drip emitters, spaghetti tubes, subsurface or surface drip tubes, low-head bubblers, and spray or mini sprinkler systems. Microirrigation systems are in extensive use around the world since its acceptance for easy control of the applied water volume and thus to irrigation management.

\footnotetext{
Assistant Prof., Agric. Eng. Dept., Fac. of Agric., Suez Canal University, 41522 Ismailia, Egypt.
} 
These systems are compatible for a wide range of crop variety, soil type, climate and land surface despite of few potentially constrains. Clogging and emission non-uniformity, for a long time, have been the major obstacles in the development of drip irrigation (Bisconer, 2010).

Energy costs are more significant than water costs in most countries. Today most irrigation techniques have been developed for conditions under which fossil energy sources deliver pump energy as needed. Low-head bubbler irrigation system is a microirrigation system that is based on gravity flow; operate at pressure heads as low as $10 \mathrm{kPa}$ from a small diameter tube (1$13 \mathrm{~mm}$ ) with a slope of $1-3 \%$. It has a large orifice opening to deliver water directly to the root zone in the form of a small stream or fountain and with discharge rates greater than that drip or subsurface emitters but generally less than $225 \ell / \mathrm{h}$. Thus this irrigation system is particularly well-suited for orchard crops, eliminating the elaborate filtration systems and pumps required by other microirrigation systems. The economical use of water and its low operating pressure makes it particularly well-suited for combination with alternative energy such as wind and solar energy water pumping systems. Despite these advantages, the low head bubbler system has not been widely used. (Carr and Kay, 1980; Yitayew et al., 1999; Omara, et al. 2004 and ASABE, 2008).

Many engineers and farmers are not aware of this technology and previously there was no well-defined design procedure or computer program available to facilitate the design and installation of these systems. Other microirrigation design softwares are unable to design low head bubbler irrigation system because delivery hose diameters must be sized to prevent airlocks and all delivery elevations must be specified to ensure equal flow. Design procedures have been developed over the last several years and are relatively unique to this type of irrigation. The design procedure was further developed by writing user-friendly software to save time, improve accuracy, and allow different design alternatives (Didan et al., 1996; Yitayew et al., 1999; Omara, et al. 2004 and Hashem et al., 2011). 
Low head bubblers are unique emitters in that they are not designed to dissipate energy, unlike those associated with the other types of microirrigation systems. These are essentially delivery tubes for transferring water from irrigation laterals to the plants (Hills and Yitayew 2007). The flow rate through the bubbler is very sensitive to changes of pressure head, so it can be altered by adjusting their outlet elevations (Hull, 1981). To maintain equal discharge from all bubblers, the heights can be adjusted according to the pressure distribution along the lateral line. The height of each bubbler was calculated by subtracting the head friction losses in the pipes and the change in elevation from the static head (Rawlins, 1977). Since the flow condition in the lateral line is steady and spatially varied with decreasing discharge in the downstream direction, the resultant energy grade line would follow an exponential curve reference. The total frictional head loss produced is inversely proportional to the bubbler height.

For new users of low head bubbler systems, software tools need to be developed to assist them to recognize full application uniformity. It should be developed to help them in adopting this new technology and to calculate system application rates and appropriate run times of irrigation systems. The objectives of this study were to:

1. Develop a computerized program to determine the optimum low head bubbler irrigation design to provide full application uniformity.

2. Validate the developed program.

\section{MATERIALS AND METHODS}

\section{Hydraulic Theory}

The hydraulic characteristics and design methods of low head bubbler laterals are very important. To solve out the problem of using bubblers with the same discharge, related hydraulic calculations are required to be considered in a step-by-step (SBS) manner. The $S B S$ procedure was applied as a start from the downstream end toward the upstream end of the lateral. Energy conservation in bubbler system design is described by Bernoulli's equation: 
$\frac{P_{1}}{\gamma}+Z_{1}+\frac{V_{1}^{2}}{2 g}=\frac{P_{2}}{r}+Z_{2}+\frac{V_{2}^{2}}{2 g}+\sum h_{f \ell}+\sum h_{m l}$

Where $h_{f \ell}=$ friction head loss in lateral pipe $(m) ; h_{m l}=$ minor losses at pipe fittings $(\mathrm{m}) ; V=$ flow velocity of water in the pipe $(\mathrm{m} / \mathrm{s}) ; P=$ pressure within the pipe $\left(\mathrm{N} / \mathrm{m}^{2}\right) ; Z=$ elevation of pipe centerline with respect to a reference datum $(\mathrm{m}) ; \gamma=$ specific weight of water $\left(\mathrm{N} / \mathrm{m}^{3}\right)$; and $\mathrm{g}=$ gravitational constant, $\left(9.81 \mathrm{~m} / \mathrm{s}^{2}\right)$.

The basic formulas of friction and other minor losses of pipeline have been applied to derive formulations of the discharges and total head in the lateral. Whilst the bubbler length is variable other design parameters such as pipe sizes, land slope, and spacing of bubblers are assumed to be constants.

In this study, Darcy-Weisbach equation was used to calculate the frictional losses in different pipes. As discharges along the lines are spatially varying, flow regimes are going to change according to the velocity conditions. Reynold's number may be calculated to know the flow regime and thereby to select the appropriate equations for estimating friction factors. Frictional head losses in pipes can be written in The International System of Units (SI) as:

$h_{f}=f \frac{L}{d} \frac{v^{2}}{2 g}$

For laminar flow, with Reynold's number less than 4000, the friction factor $f$ can be written as:

$f=\frac{64}{R_{e}}$

For turbulent flow with Reynold's number between 4000 and 100,000, Blasius equation gives a good approximation for computing friction factor $f$, which can be written as:

$f=\frac{0.3164}{R_{e}^{0.25}}$

Where, $R_{e}=$ Reynold's number, (dimensionless); $L$ and $d=$ length and diameter of the pipes $(\mathrm{m})$; and $v=$ velocity of flow $(\mathrm{m} / \mathrm{s})$. 
Due to water temperature affecting flow rate in the lateral and bubblers, the effects of viscosity on the flow rate give a more accurateresults. Hydraulically, flow regimes can be characterized by the Reynold's number $\left(R_{e}\right)$, which may be expressed in terms of the water temperature that is given by Boor et al. (1968), as follows:

$$
R_{e}=198.7 Q\left(1+0.03368 T_{w}+0.000221 T_{w}^{2}\right) / d
$$

Where $Q=$ the total flow rate $(\ell / h) ; T_{w}=$ the water temperature $\left({ }^{\circ} C\right)$ and $d$ $=$ internal pipe diameter $(\mathrm{mm})$. Equations (2-4) can be combined to obtain the equations for laminar (Eq 6) and turbulent (Eq 7) flows, respectively as follows:

$$
\begin{aligned}
& h_{f}=408.4479 \frac{L Q^{2}}{R_{e} d^{5}} \\
& h_{f}=2.01926 \frac{L Q^{2}}{R_{e}^{0.25} d^{5}}
\end{aligned}
$$

Where $h_{f}=$ frictional head loss $(m) ; L=$ length of pipe $(m) ; Q=$ discharge (liter $/ \mathrm{hr}) ; D=$ inside pipe diameter $(\mathrm{mm})$.

Watters and Keller (1978) presented the barbed friction minor losses $\left(E_{\ell}\right)$ in terms of a length of lateral that produces a friction loss of the same magnitude of the localized loss produced by the barb. They presented emitter barb losses for various pipe diameter and barb dimensions as follows:

$$
E_{\ell}=0.25 d_{b}\left(19 d_{\ell}^{-19}\right)
$$

Where $\mathrm{E}_{\ell}=$ equivalent length of pipe $(m) ; d_{b}=$ emitter barb diameter $(\mathrm{mm})$ and $d_{\ell}=$ diameter of lateral $(\mathrm{mm})$. Therefore, the distance between bubblers $\delta$ in the frictional head loss equation of lateral was substituted by $\delta_{\ell}$ after adding the equivalent length $E_{\ell}$.

$\delta_{L}=\left(\delta+E_{\ell}\right)$

Velocity and other minor losses of the system can be written in general form as.

$$
h=k \frac{v^{2}}{2 g}
$$


Where, $\mathrm{k}=$ head loss coefficient, which in two different minor loss coefficients are differentiated as: $\mathrm{k}_{\mathrm{e}}=1.2$, to calculate entrance head loss $h_{e}$, assuming the entrance from lateral as a reentrant one and $\mathrm{k}_{\mathrm{v}}=1$, to calculate velocity head $h_{v}$. Thus, Eq (10) can be rearranged to accommodate for these two different minor loss as follows:

$$
\begin{aligned}
& h_{e}=0.0077 \frac{q^{2}}{d^{4}} \\
& h_{v}=0.0064 \frac{q^{2}}{d^{4}}
\end{aligned}
$$

Model Development to Determine the Optimum Low Head Bubbler Design Figure (1) shows the bubbler Hydraulic Grade Line $H G L$ which was parallel to the lateral Hydraulic Grade Line $H G L$. The bubbler head loss of entrance $\left(h_{e}\right)$, velocity $\left(h_{v}\right)$ and friction $\left(h_{f b}\right)$ along the lateral were kept unchanged by keeping the same discharge $\left(q_{b}\right)$ and length $\left(\ell_{b}\right)$ along the lateral pipe. It is obvious that the heights of bubbler decreased gradually along the horizontal lateral from upstream toward downstream end $\left.\left.\left.\left.h_{h(1)}\right\rangle h_{h(2)}\right\rangle h_{h(3)}\right\rangle h_{h(4)}\right\rangle{ }_{(h(n)}=$ $\left.h_{h(\text { min })}\right)$, to compensate the lateral friction loss $\left(h_{f \ell}\right)$ and obtaining equal bubbler discharges $q_{b(1)}=q_{b(2)}=\ldots=q_{b(n)}$.

Total head of the bubbler inlet $\left(h_{n}\right)$ at the outlet point number $n$ in the lateral downstream end with minimum height could be calculated by summing all the head losses as follows:

$$
h_{e}+h_{v}+h_{f b(n)}+h_{h(n)}=h_{n}
$$

By substituting full expressions for each of the head balance terms will result totally in two equations for laminar and turbulent flow in the minimum bubbler height $\left(h_{n}\right)$ as follows:

1. The bubbler flow regime is laminar.

$0.0077 \frac{q_{b}^{2}}{d_{b}^{4}}+0.0064 \frac{q_{b}^{2}}{d_{b}^{4}}+408.4479 \frac{\ell_{b} q_{b}^{2}}{R_{e(b)} d_{b^{5}}^{5}}+h_{h(n)}=h_{n}$

2. The bubbler flow regime is turbulent.

$0.0077 \frac{q_{b}^{2}}{d_{b}^{4}}+0.0064 \frac{q_{b}^{2}}{d_{b}^{4}}+2.01926 \frac{\ell_{b} q_{b}^{2}}{R_{e(b)}^{0.25} d_{b^{5}}^{5}}+h_{h(n)}=h_{n}$ 
Where, $q_{b}=$ bubbler discharge (liter $\left./ h r\right) ; d=$ bubbler pipe inside diameter $(\mathrm{mm}) ; \ell_{b}=$ length of bubbler pipe $(\mathrm{m}) ; \boldsymbol{R}_{e(b)}=$ Reynold's number of the bubbler flow (dimensionless); $h_{h(n)}=$ the minimum bubbler height at outlet point number $n$ on the lateral end $(m)$.

The balance of energy heads between two successive outlet points $(n-1$ and $n)$ could be written as:

$h_{e(n-1)}+h_{v(n-1)}+h_{f b(n-1)}+h_{h(n-1)}=h_{e(n)}+h_{v(n)}+h_{f b(n)}+h_{h(n)}+h_{f \ell(n)} \pm S \delta_{L}$

Where $h_{f \ell}=$ frictional head loss of lateral at the distance before bubbler outlet point number $n(m) ; S=$ slope of lateral (\%); (n-1) $\&(n)=$ bubbler outlet point numbers; and $\delta_{L}=$ distance between bubblers $(m)$.

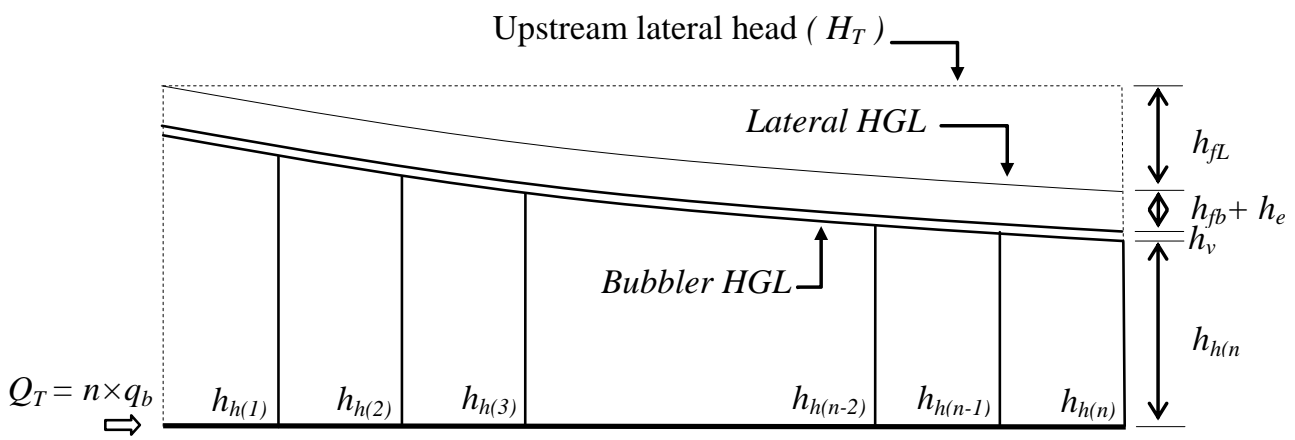

Figure (1). Upstream lateral head $\left(H_{T}\right)$, lateral and bubbler Hydraulic Grade Line $(H G L)$, lateral and bubbler friction losses $\left(h_{f L}, h_{f b}\right)$, entrance head loss $h_{e}$, velocity head $\left(h_{v}\right)$ and bubbler heights $\left(h_{h}\right)$ along the horizontal low head bubbler irrigation lateral.

Since the effective pressure head $h_{e f}$ which include the entrance head loss $\left(h_{e}\right)$, velocity loss $\left(h_{v}\right)$ and friction loss $\left(h_{f b}\right)$ for all bubblers along the lateral are same, so that Eq (16) could be written to calculate the bubbler height as follow:

$$
h_{h(n-1)}=h_{h(n)}+h_{f \ell(n)} \pm S \delta_{L}
$$

The bubbler height will result in total two equations for laminar and turbulent flow in lateral as follows: 
1. The lateral flow regime is laminar.

$h_{b}(n-1)=h_{b}(n)+408.4479 \frac{\delta_{L} Q^{2}}{R_{e(L)} D^{5}} \pm S \delta_{L}$

2. The lateral flow regime is turbulent.

$$
h_{h(n-1)}=h_{h(n)}+2.01926 \frac{\delta_{L} Q^{2}}{R_{e(L)}^{0.25} D^{5}} \pm S \delta_{L}
$$

Where, $R_{e(L)}=$ Reynold's number of the lateral pipe flow (dimensionless);

Therefore, the only unknown $h_{h(n-1)}$ can be calculated directly from the above equations when the required bubbler discharge $\left(q_{b}\right)$, bubbler diameter $\left(d_{b}\right)$, bubbler tube length $\left(\ell_{b}\right)$, the minimum bubbler height $\left(h_{h(\min )}=h_{h(n)}\right)$, the maximum bubbler height $\left(h_{h(\max )}=h_{h(1)}\right)$, lateral diameter $\left(d_{L}\right)$, distance between bubblers $\left(\delta_{L}\right)$, lateral slope $(S)$, allowable upstream pressure head $H_{a l}$ and water temperature $\left(T_{w}\right)$ are all known parameters. Proceeding in this manner up to the lateral upstream, all the bubbler heights will be calculated to deliver equal discharges $(q)$. There are two points to ending the calculations if one of them is appearing, when the bubbler height $\left(h_{h(1)}\right)$ would be equal to the maximum bubbler height $h_{h(\max )}$; or the lateral upstream pressure head $\left(H_{T}\right)$ would be equal to allowable pressure head $H_{a l}$, whichever is earlier. When the computation of bubbler height's stops, the upstream press(u) head $H_{T}$ would be computed as:

$$
H_{T}=h_{e}+h_{v}+h_{f b}+h_{h(1)}+h_{f L(1)} \pm S \delta_{L}
$$

Where, $h_{h(1)}=$ the maximum bubbler height at outlet point number one at the lateral upstream end $(m) ; h_{f L(1)}=$ frictional head loss of lateral at the distance before outlet point one $(m)$. The total number of bubblers $b_{T}$, maximum lateral length $L_{\max }(m)$ and the total upstream lateral end discharge $Q_{T}$ (liter/hr) calculated as follows:

$$
\begin{aligned}
& b_{T}=o_{n} \times \text { Number of bubbler per outlet point } \\
& Q_{T}=b_{n} \times q_{b}
\end{aligned}
$$




$$
L_{\max }=o_{n} \times \delta
$$

Where, $O_{n}=$ outlet point numbers. Figure (2) shows the computational computer program for designing single low head bubbler lateral line.

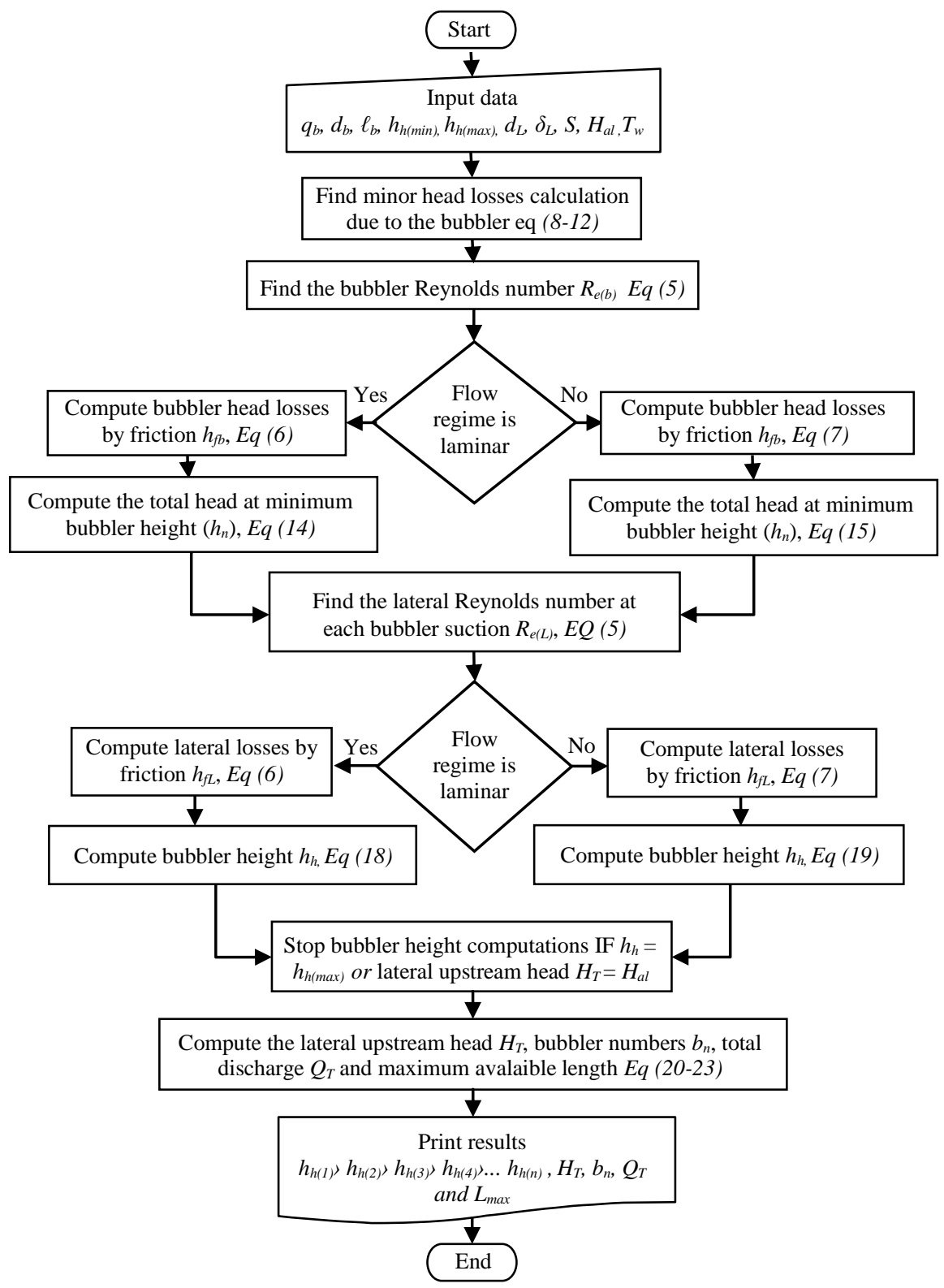

Figure (2): Flowchart of developed computer program for designing single low head bubbler lateral line. 


\section{Design Example}

A design example of the developed program is presented using four bubbler tube sizes. A laboratory experiment to evaluate this design example was carried out in Hydraulic Laboratory of the Agricultural Engineering Department, Faculty of Agriculture, Suez Canal University, Ismailia, Egypt.

Figure 3 shows schematic diagram of the required low head bubbler irrigation lateral, which can irrigate two rows at a distance of $6.0 \times 6.0 m$. Then, the distances between laterals are $12 \mathrm{~m}$, which buried in soil at depth of $0.5 \mathrm{~m}$. The bubbler lengths are constantly on the lateral line, which equal to $3.0 m$ from the inlet to tree location, adding $0.5 \mathrm{~m}$ to reach the soil surface in addition to $1.0 \mathrm{~m}$ over the soil surface, the total length is $4.5 \mathrm{~m}$. The distance between each two consecutive bubblers is $6.0 \mathrm{~m}$, the bubbler inside diameter's $d_{b}$ (ID 3.8, 6.0, 10.0 and 13.6mm), and bubbler discharges $q_{b}(10$ to $230 \mathrm{l} / \mathrm{h})$ with $20^{\circ} \mathrm{C}$ water temperature. The minimum bubbler height at downstream end $h_{h(\min )}$ was taken as $0.3 m$ and the maximum height $h_{h(1)}$ was assumed to be less than or equal to $1 \mathrm{~m}$ at the lateral upstream end. The lateral inside diameter $d_{L}$ is (ID 63mm) on a level terrain and allowable lateral upstream head $H_{a l}(1,1.5 \mathrm{~m})$. The available lateral upstream head is $1.0 \mathrm{~m}$ or $1.5 \mathrm{~m}$.

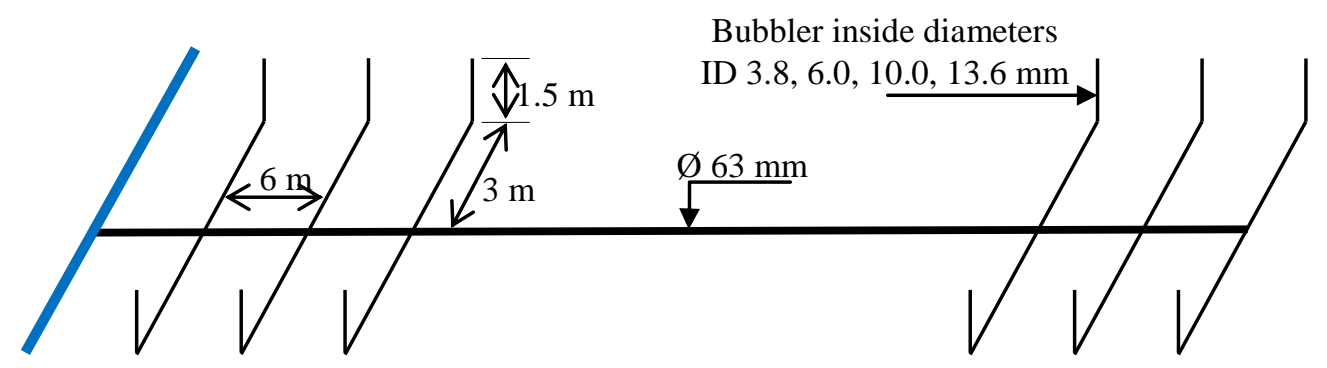

Figure (3): Schematic diagram of the required low head bubbler irrigation lateral to irrigate two rows at distance of $6.0 \times 6.0 \mathrm{~m}$. 


\section{The Laboratory Experiment}

The laboratory experiment was studying the relationship between the effective pressure head $h_{e f}$ and bubbler discharge. This relationship was tested with the same bubbler sizes $(3.8,6.0,10.0$ and $13.6 \mathrm{~mm}$ ) and $4.5 \mathrm{~m}$ length as the design example. The schematic representation of the test apparatus is shown in Fig. 4. Different effective pressure heads $\left(h_{e f}\right)$ from $(1.0$ to $2.0 m)$ with an increment of $(0.1 \mathrm{~m})$ was used for the bubbler system under investigation. Ten bubbler tubes of each size were mounted at $0.5 \mathrm{~m}$ distance between it on the lateral pipe (ID $88.9 \mathrm{~mm}$ ) and the discharges were measured at different pressures. The pressure was monitored by using three piezometric tubes placed at the beginning, middle and the end of the lateral pipe. The experiment was repeated three times at different pressures for each bubbler diameter. The constant values of effective head-discharge equation were determined by power regression between measured discharges, $q\left(\ell / h\right.$.) versus effective pressure head, $h_{e f}(m)$.

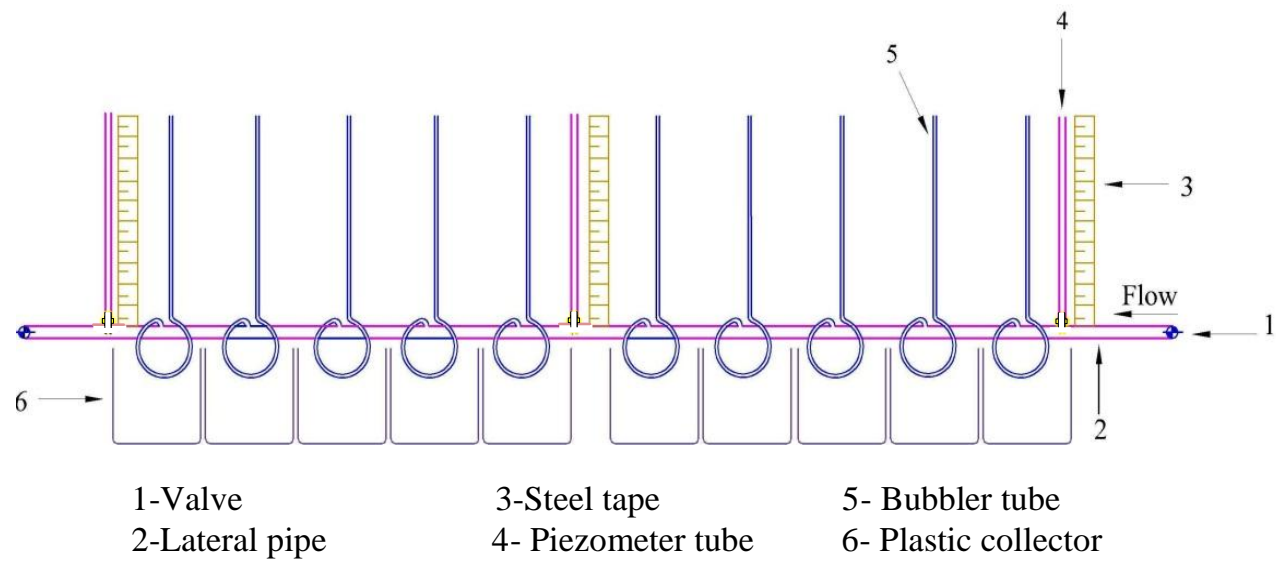

Figure (4): Setup schematic diagram of the apparatus used to test the relationship between the effective pressure head and bubbler discharge. 


\section{RESULTS AND DISCUSSION}

\section{Typical Low Head Bubbler Lateral Design}

The key of success in proper design of a low head bubbler system is the achievement of full application uniformity. The design example shows how can be introducing the available design solutions for the required low head irrigation lateral by the program. Summarized results in Table (1), shows the results for different inputted data. In terms of maximum bubbler outlet numbers $O_{n}$, lateral length $L_{\max }(m)$, bubbler height $h_{h(\max )}(m)$, and the lateral pressure head $H_{T}(m)$. Developed program prints up the details of these results for each outlet point in addition to total bubbler numbers $b_{T}$ and the total discharge at lateral upstream end $Q_{T}($ liter $/ \mathrm{hr})$.

Figure (5) shows the relationship between bubbler discharges versus effective pressure head, $h_{e f}$. All R-squared value was above 0.95 and the discharge equation constants were determined for each bubbler diameter. By these equations, it could be calculating the effective pressure versus every bubbler discharge of each bubbler size.

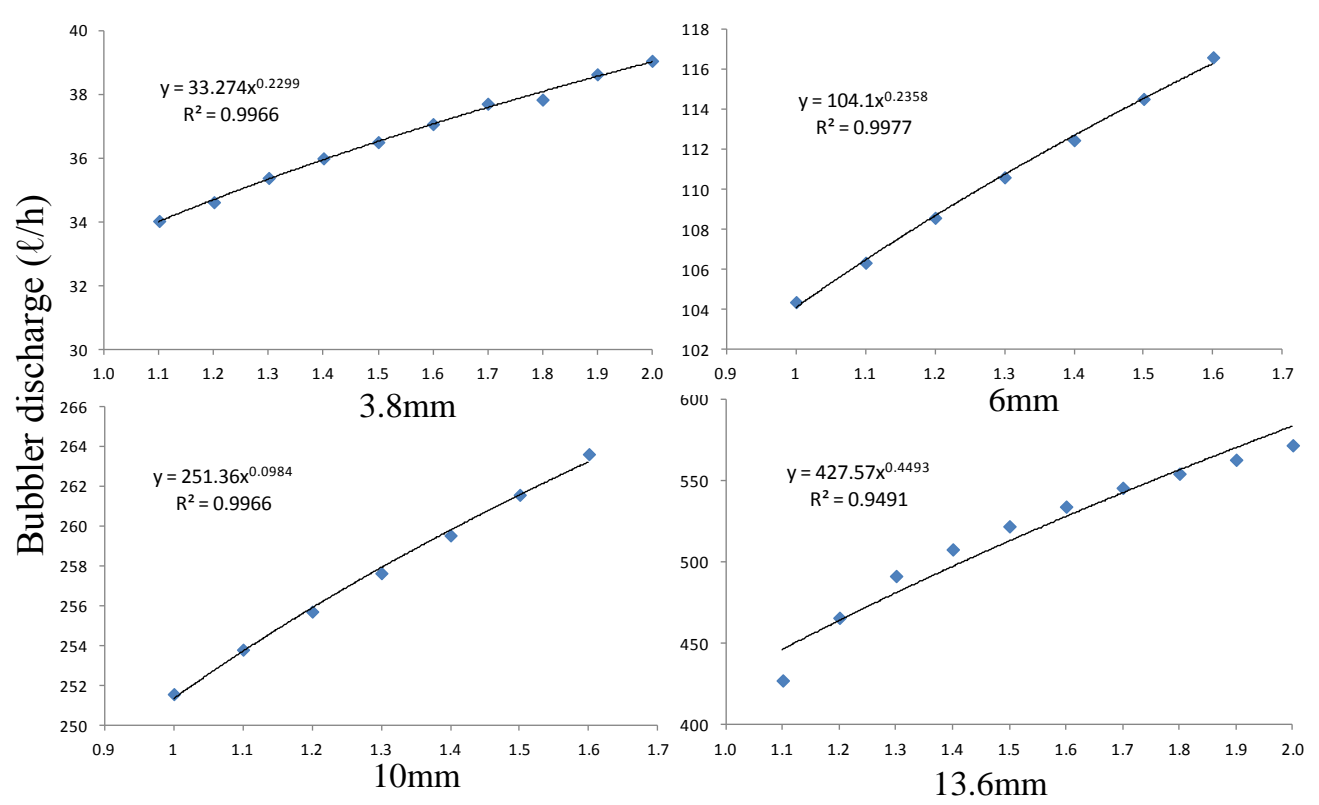

Effective pressure head, $\mathrm{h}_{\mathrm{ef}}(m)$

Figure (5): The relationship between effective pressure head $\left(\mathrm{h}_{\mathrm{ef}}\right)$ and bubbler discharge $q_{b}$ for different diameters. 
At this point, it could be calculating the bubbler hydraulic grade line $H G L$ and lateral $H G L$. Then, it could be compared to the theoretical design of the developed program with the actual design.

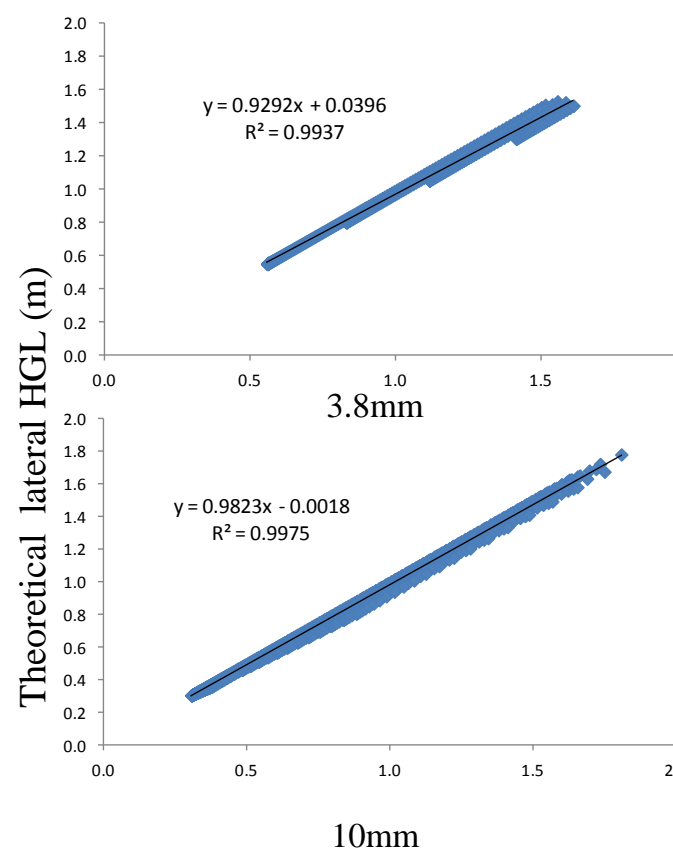

Experimental Lateral HGL $(m)$

Figure (6): The relationship between theoretical and experimental Lateral Hydraulic Grade Line, HGL (m).

Figure (6) shows the relationship between theoretical Lateral Hydraulic Grade Line $H G L$ calculated by the program and by laboratory experiment HGL. All R-squared value was above 0.99 for tested bubbler diameters, which means that a high correlation between the results obtained by developed program and actual results. This is empirical evidence on the accuracy of the program for low head bubbler design. 
As seen in Table (1), the bubbler diameter $d_{b}$ and discharge $q_{b}$ had the main effect on maximum bubbler height $h_{h(\max )}$ and as a result, outlet point numbers $O_{n}$ and lateral length $L_{\max }$. The small bubbler diameters $d_{b}$ couldn't be used to meet relatively large discharges due to the increase in bubbler friction loss.

The increase in the allowable pressure heads $H_{a l}$ from 1 to $1.5 \mathrm{~m}$ had different effects on bubble numbers on the lateral line for different diameters. The $H_{a l}$ had a slight effect on bubbler diameters (10.0 and 13.6mm); meanwhile, it had a great influence on small diameters $(3.8$ and $6.0 \mathrm{~mm})$. Where the bubbler discharges $q_{b}$ at $H_{a l}$ of $1 \mathrm{~m}$ with diameters of 3.8 and $6 \mathrm{~mm}$ were 20 and $60 \mathrm{\ell} / \mathrm{h}$, respectively. While, the discharges were increased at $H_{a l} 1.5 \mathrm{~m}$ to 40 and $80 \mathrm{l} / \mathrm{h}$ for the same diameters, correspondingly. This could be ascribed to the high friction loss in case of small diameters. This explains the proportional direction between the maximum bubbler height $h_{h(\max )}$ and bubbler diameter $d_{b}$. When the maximum bubbler height $h_{h(\max )}$ limit exceeds than $1 m$ the bubbler numbers were increased in case of 10.0 and $13.6 \mathrm{~mm}$ diameters, whereas it had a slight effect on small diameters 3.8 and $6.0 \mathrm{~mm}$.

However, it is hoped that the information contained in this example contributes to a better understanding of how and why the low-head bubbler irrigation needs to be adopted on more and more of the irrigated area each year. It is hoped that this information will serve as a pattern to guide those who are interested in adopting and managing bubbler systems on fruit trees, and spurs research. 
Table (1). Maximum bubbler outlet point numbers $o_{n}$, maximum lateral length $L_{\max }(m)$, Maximum bubbler height $h_{h(\max )}(m)$, and the lateral upstream pressure head $H_{T}(\mathrm{~m})$ when its allowable lateral upstream head $H_{a l}, 1.0 \mathrm{~m}(1.5 \mathrm{~m})$ for each bubbler discharge $q_{b}(\ell / \mathrm{h})$ and diameter $d_{b}$.

\begin{tabular}{|c|c|c|c|c|c|c|c|c|c|c|c|c|c|c|c|c|}
\hline \multirow[b]{2}{*}{$\begin{array}{l}q_{b} \\
\ell / \mathrm{h}\end{array}$} & \multicolumn{4}{|c|}{$d_{b}=13.6 \mathrm{~mm}$} & \multicolumn{4}{|c|}{$d_{b}=10 \mathrm{~mm}$} & \multicolumn{4}{|c|}{$d_{b}=6 \mathrm{~mm}$} & \multicolumn{4}{|c|}{$\mathrm{d}_{\mathrm{b}}=3.8 \mathrm{~mm}$} \\
\hline & $\begin{array}{c}O_{n} \\
n\end{array}$ & \begin{tabular}{|c|}
$L_{\max }$ \\
$m$
\end{tabular} & \begin{tabular}{|c|}
$h_{h(\max )}$ \\
$m$
\end{tabular} & $\begin{array}{c}H_{T} \\
m\end{array}$ & $\begin{array}{c}O_{n} \\
n\end{array}$ & $\begin{array}{c}L_{\max } \\
m\end{array}$ & $\begin{array}{c}h_{h(\max )} \\
m\end{array}$ & $\begin{array}{c}H_{T} \\
m\end{array}$ & $\begin{array}{c}O_{n} \\
n\end{array}$ & $\begin{array}{c}L_{\max } \\
m\end{array}$ & $\begin{array}{c}h_{h(\max )} \\
m\end{array}$ & $\begin{array}{c}H_{T} \\
m\end{array}$ & $\begin{array}{c}O_{n} \\
n\end{array}$ & $\begin{array}{c}L_{\max } \\
m\end{array}$ & \begin{tabular}{|c}
$h_{h(\max )}$ \\
$m$
\end{tabular} & $\begin{array}{c}H_{T} \\
m\end{array}$ \\
\hline 10 & \begin{tabular}{|c|}
165 \\
$(167)$
\end{tabular} & $\begin{array}{c}990 \\
(1002)\end{array}$ & $\begin{array}{l}0.98 \\
(1.0)\end{array}$ & $\begin{array}{l}0.99 \\
1.01\end{array}$ & \begin{tabular}{|c|}
165 \\
$(167)$
\end{tabular} & $\begin{array}{c}990 \\
(1002)\end{array}$ & $\begin{array}{l}0.98 \\
(1.0)\end{array}$ & $\begin{array}{l}1.00 \\
1.02\end{array}$ & $\begin{array}{c}162 \\
(167)\end{array}$ & $\begin{array}{c}972 \\
(1002)\end{array}$ & $\begin{array}{l}0.94 \\
(1.0)\end{array}$ & $\begin{array}{l}1.00 \\
1.05\end{array}$ & \begin{tabular}{|c|}
140 \\
$(167)$
\end{tabular} & \begin{tabular}{|c|c}
840 \\
$(1002)$ \\
\end{tabular} & \begin{tabular}{|c}
0.73 \\
$(1.0)$
\end{tabular} & $\begin{array}{l}1.00 \\
1.27\end{array}$ \\
\hline 20 & $\begin{array}{c}106 \\
(107)\end{array}$ & $\begin{array}{c}636 \\
(642)\end{array}$ & $\begin{array}{c}0.98 \\
(0.99)\end{array}$ & $\begin{array}{l}1.00 \\
1.01\end{array}$ & $\begin{array}{c}105 \\
(108)\end{array}$ & \begin{tabular}{|c|}
630 \\
$(642)$
\end{tabular} & $\begin{array}{c}0.96 \\
(0.99)\end{array}$ & $\begin{array}{l}0.99 \\
1.02\end{array}$ & $\begin{array}{c}101 \\
(107)\end{array}$ & $\begin{array}{c}606 \\
(642)\end{array}$ & $\begin{array}{c}0.89 \\
(0.99)\end{array}$ & \begin{tabular}{|l|}
0.99 \\
1.09
\end{tabular} & $\begin{array}{c}63 \\
(104)\end{array}$ & \begin{tabular}{|c}
378 \\
$(624)$
\end{tabular} & $\begin{array}{c}0.46 \\
(0.94)\end{array}$ & $\begin{array}{l}1.00 \\
1.49\end{array}$ \\
\hline 30 & $\begin{array}{c}81 \\
(83)\end{array}$ & $\begin{array}{c}486 \\
(498)\end{array}$ & $\begin{array}{l}0.95 \\
(1.0)\end{array}$ & $\begin{array}{c}0.98 \\
(1.03)\end{array}$ & \begin{tabular}{|c|}
81 \\
$(83)$
\end{tabular} & $\begin{array}{c}486 \\
(498)\end{array}$ & $\begin{array}{l}0.95 \\
(1.0)\end{array}$ & \begin{tabular}{|c}
0.99 \\
$(1.04)$
\end{tabular} & $\begin{array}{c}76 \\
(83)\end{array}$ & $\begin{array}{c}456 \\
(498)\end{array}$ & \begin{tabular}{|c|}
0.85 \\
$(1.0)$
\end{tabular} & \begin{tabular}{|c}
1.00 \\
$(1.15)$
\end{tabular} & \begin{tabular}{|c|}
--- \\
$(65)$ \\
\end{tabular} & \begin{tabular}{|c}
--- \\
$(390)$ \\
\end{tabular} & \begin{tabular}{|c|}
--- \\
$(0.65)$
\end{tabular} & $(1.48)$ \\
\hline 40 & $\begin{array}{c}68 \\
(69)\end{array}$ & $\begin{array}{c}408 \\
(414)\end{array}$ & $\begin{array}{c}0.97 \\
(0.99)\end{array}$ & \begin{tabular}{|c}
1.00 \\
$(1.03)$
\end{tabular} & \begin{tabular}{|c|}
67 \\
$(69)$ \\
\end{tabular} & $\begin{array}{c}402 \\
(414)\end{array}$ & $\begin{array}{c}0.94 \\
(0.99)\end{array}$ & $\begin{array}{c}0.99 \\
(1.04)\end{array}$ & $\begin{array}{c}61 \\
(69)\end{array}$ & $\begin{array}{c}366 \\
(414)\end{array}$ & $\begin{array}{c}0.79 \\
(0.99)\end{array}$ & $\begin{array}{c}0.99 \\
(1.20)\end{array}$ & (31) & \begin{tabular}{|c|}
---- \\
$186)$
\end{tabular} & $\begin{array}{c}--- \\
(0.37)\end{array}$ & $(1.50)$ \\
\hline 50 & \begin{tabular}{|c|}
58 \\
$(60)$
\end{tabular} & \begin{tabular}{|c|}
348 \\
$(360)$
\end{tabular} & $\begin{array}{l}0.93 \\
(1.0)\end{array}$ & $\begin{array}{c}0.97 \\
(1.04)\end{array}$ & \begin{tabular}{|c|}
58 \\
$(60)$
\end{tabular} & \begin{tabular}{|c|}
348 \\
$(360)$
\end{tabular} & $\begin{array}{c}0.93 \\
(0.99)\end{array}$ & $\begin{array}{c}0.99 \\
(1.06)\end{array}$ & $\begin{array}{c}51 \\
(60)\end{array}$ & $\begin{array}{c}306 \\
(360)\end{array}$ & $\begin{array}{c}74 \\
(0.99)\end{array}$ & $\begin{array}{c}1.00 \\
(1.26)\end{array}$ & & & & \\
\hline 60 & $\begin{array}{c}52 \\
(53)\end{array}$ & $\begin{array}{c}312 \\
(318)\end{array}$ & $\begin{array}{c}0.94 \\
(0.98)\end{array}$ & \begin{tabular}{|c}
0.99 \\
$(1.02)$
\end{tabular} & \begin{tabular}{|c}
51 \\
$(53)$ \\
\end{tabular} & $\begin{array}{c}306 \\
(318)\end{array}$ & $\begin{array}{c}0.91 \\
(0.98)\end{array}$ & $\begin{array}{c}0.98 \\
(1.05)\end{array}$ & \begin{tabular}{|l|}
43 \\
$(53$
\end{tabular} & $\begin{array}{c}258 \\
(318)\end{array}$ & $\begin{array}{c}68 \\
(0.98)\end{array}$ & $\begin{array}{c}0.99 \\
(1.29)\end{array}$ & & & & \\
\hline 70 & \begin{tabular}{|c|}
47 \\
$(48)$
\end{tabular} & $\begin{array}{c}282 \\
(288)\end{array}$ & $\begin{array}{c}0.94 \\
(0.98)\end{array}$ & \begin{tabular}{|c}
0.99 \\
$(1.03)$
\end{tabular} & \begin{tabular}{|c|}
46 \\
$(48)$ \\
\end{tabular} & \begin{tabular}{|c}
$\begin{array}{c}276 \\
(288)\end{array}$ \\
\end{tabular} & $\begin{array}{c}0.90 \\
(0.97)\end{array}$ & $\begin{array}{c}0.98 \\
(1.06)\end{array}$ & \begin{tabular}{|c|}
---- \\
(39) \\
\end{tabular} & \begin{tabular}{|c|}
--- \\
$(234)$
\end{tabular} & \begin{tabular}{|c|}
--- \\
$(0.68)$
\end{tabular} & \begin{tabular}{|c|}
--- \\
$(1.47)$ \\
\end{tabular} & & & & \\
\hline 80 & \begin{tabular}{|c|}
43 \\
$(44)$ \\
\end{tabular} & $\begin{array}{c}258 \\
(264)\end{array}$ & $\begin{array}{c}0.93 \\
(0.97)\end{array}$ & \begin{tabular}{|c}
0.98 \\
$(1.03)$ \\
\end{tabular} & \begin{tabular}{|c|}
42 \\
$(44)$ \\
\end{tabular} & \begin{tabular}{|c}
252 \\
$(264)$
\end{tabular} & $\begin{array}{c}0.89 \\
(0.97)\end{array}$ & \begin{tabular}{|c|}
0.98 \\
$(1.06)$
\end{tabular} & \begin{tabular}{|c|}
--- \\
(28)
\end{tabular} & $\begin{array}{c}---- \\
(168)\end{array}$ & $\begin{array}{c}--- \\
(0.49)\end{array}$ & $\begin{array}{c}--- \\
(1.48) \\
\end{array}$ & & & & \\
\hline 90 & \begin{tabular}{|c|}
40 \\
$(41)$
\end{tabular} & $\begin{array}{c}240 \\
(246)\end{array}$ & $\begin{array}{c}0.93 \\
(0.98)\end{array}$ & \begin{tabular}{|c}
0.99 \\
$(1.04)$
\end{tabular} & \begin{tabular}{|c|}
39 \\
$(41)$
\end{tabular} & $\begin{array}{c}234 \\
(246)\end{array}$ & $\begin{array}{c}0.89 \\
(0.98)\end{array}$ & \begin{tabular}{|c}
0.99 \\
$(1.08)$
\end{tabular} & & & & & & & & \\
\hline 100 & \begin{tabular}{|c|}
37 \\
$(38)$
\end{tabular} & $\begin{array}{c}222 \\
(228)\end{array}$ & \begin{tabular}{|c|}
0.91 \\
$(0.96)$
\end{tabular} & \begin{tabular}{|c}
0.98 \\
$(1.02)$
\end{tabular} & \begin{tabular}{|c}
36 \\
$(38)$
\end{tabular} & $\begin{array}{c}\begin{array}{c}216 \\
(228)\end{array} \\
\end{array}$ & $\begin{array}{c}0.87 \\
(0.96)\end{array}$ & $\begin{array}{c}0.97 \\
(1.07)\end{array}$ & & & & & & & & \\
\hline 110 & \begin{tabular}{|c|}
35 \\
$(36)$ \\
\end{tabular} & $\begin{array}{c}210 \\
(216)\end{array}$ & $\begin{array}{c}0.92 \\
(0.97)\end{array}$ & \begin{tabular}{|c|c}
0.99 \\
$(1.04)$
\end{tabular} & \begin{tabular}{|c|}
34 \\
$(36)$ \\
\end{tabular} & $\begin{array}{c}204 \\
(216)\end{array}$ & $\begin{array}{c}0.87 \\
(0.97) \\
\end{array}$ & $\begin{array}{c}0.99 \\
(1.09)\end{array}$ & & & & & & & & \\
\hline 120 & \begin{tabular}{|c|}
33 \\
$(34)$ \\
\end{tabular} & \begin{tabular}{|c|}
198 \\
$(204)$
\end{tabular} & $\begin{array}{c}0.91 \\
(0.96)\end{array}$ & \begin{tabular}{|c|}
0.99 \\
$(1.04)$
\end{tabular} & \begin{tabular}{|c}
30 \\
$(34)$ \\
\end{tabular} & $\begin{array}{c}180 \\
(204)\end{array}$ & \begin{tabular}{|c|}
0.77 \\
$(0.96)$ \\
\end{tabular} & \begin{tabular}{|c}
0.99 \\
$(1.20)$
\end{tabular} & & & & & & & & \\
\hline 130 & \begin{tabular}{c|}
31 \\
$(32)$
\end{tabular} & $\begin{array}{c}186 \\
(192)\end{array}$ & $\begin{array}{c}0.89 \\
(0.94)\end{array}$ & \begin{tabular}{|c|}
0.97 \\
$(1.03)$
\end{tabular} & \begin{tabular}{|c|}
28 \\
$(33)$
\end{tabular} & $\begin{array}{c}168 \\
(198)\end{array}$ & \begin{tabular}{|l|}
0.74 \\
$(1.0)$
\end{tabular} & $\begin{array}{l}1.00 \\
(1.27)\end{array}$ & & & & & & & & \\
\hline 140 & $\begin{array}{c}30 \\
(31)\end{array}$ & $\begin{array}{c}180 \\
(186)\end{array}$ & \begin{tabular}{|c|}
0.91 \\
$(0.97)$
\end{tabular} & \begin{tabular}{|l}
1.00 \\
$(1.06)$
\end{tabular} & \begin{tabular}{|c}
26 \\
$(31)$
\end{tabular} & $\begin{array}{c}156 \\
(186)\end{array}$ & $\begin{array}{c}0.71 \\
(0.97)\end{array}$ & $\begin{array}{c}0.99 \\
(1.27)\end{array}$ & & & & & & & & \\
\hline 150 & \begin{tabular}{|c|}
28 \\
$(30)$
\end{tabular} & $\begin{array}{c}168 \\
(180)\end{array}$ & $\begin{array}{c}0.87 \\
(0.99)\end{array}$ & \begin{tabular}{|c}
0.96 \\
$(1.02)$
\end{tabular} & \begin{tabular}{|c|}
24 \\
$(30)$ \\
\end{tabular} & $\begin{array}{c}144 \\
(180)\end{array}$ & $\begin{array}{c}0.67 \\
(0.99)\end{array}$ & $\begin{array}{c}0.98 \\
(1.33)\end{array}$ & & & & & & & & \\
\hline 160 & \begin{tabular}{|c|}
26 \\
$(29)$
\end{tabular} & $\begin{array}{c}156 \\
(174)\end{array}$ & $\begin{array}{l}0.82 \\
(1.0)\end{array}$ & $\begin{array}{c}0.95 \\
(1.14)\end{array}$ & \begin{tabular}{|c}
22 \\
$(29)$
\end{tabular} & $\begin{array}{c}132 \\
(174)\end{array}$ & $\begin{array}{l}0.62 \\
(1.0)\end{array}$ & $\begin{array}{c}0.97 \\
(1.37)\end{array}$ & & & & & & & & \\
\hline 170 & \begin{tabular}{|c|}
25 \\
$(27)$ \\
\end{tabular} & $\begin{array}{c}150 \\
(160)\end{array}$ & $\begin{array}{c}0.82 \\
(0.94)\end{array}$ & \begin{tabular}{|c}
0.95 \\
$(1.09)$
\end{tabular} & \begin{tabular}{|c|}
21 \\
$(27)$ \\
\end{tabular} & $\begin{array}{c}126 \\
(162)\end{array}$ & \begin{tabular}{|c|}
0.62 \\
$(0.94)$
\end{tabular} & $\begin{array}{l}1.00 \\
(1.34)\end{array}$ & & & & & & & & \\
\hline 180 & \begin{tabular}{|c|}
24 \\
$(26)$
\end{tabular} & $\begin{array}{c}144 \\
(156)\end{array}$ & $\begin{array}{c}0.81 \\
(0.94)\end{array}$ & \begin{tabular}{|c|}
0.96 \\
$(1.09)$
\end{tabular} & \begin{tabular}{|c|}
19 \\
$(26)$ \\
\end{tabular} & $\begin{array}{c}114 \\
(156)\end{array}$ & \begin{tabular}{|c|}
0.56 \\
$(0.94)$
\end{tabular} & \begin{tabular}{|c}
0.98 \\
$(1.38)$
\end{tabular} & & & & & & & & \\
\hline 190 & $\begin{array}{c}23 \\
(26)\end{array}$ & $\begin{array}{c}138 \\
(156)\end{array}$ & $\begin{array}{l}0.80 \\
(1.0)\end{array}$ & $\begin{array}{c}0.95 \\
(1.17)\end{array}$ & \begin{tabular}{|c|}
17 \\
$(26)$
\end{tabular} & $\begin{array}{c}102 \\
(156)\end{array}$ & \begin{tabular}{|l|}
0.51 \\
$(1.0)$
\end{tabular} & $\begin{array}{c}0.96 \\
(1.49)\end{array}$ & & & & & & & & \\
\hline 200 & $\begin{array}{c}22 \\
(25)\end{array}$ & $\begin{array}{c}132 \\
(150)\end{array}$ & $\begin{array}{c}0.78 \\
(0.99)\end{array}$ & \begin{tabular}{|c|}
0.95 \\
$(1.17)$
\end{tabular} & \begin{tabular}{|c|}
16 \\
$(24)$
\end{tabular} & $\begin{array}{c}96 \\
(144)\end{array}$ & $\begin{array}{c}0.49 \\
(0.91)\end{array}$ & $\begin{array}{l}0.98 \\
(1.43)\end{array}$ & & & & & & & & \\
\hline 210 & \begin{tabular}{|c|}
21 \\
$(24)$
\end{tabular} & $\begin{array}{c}126 \\
(144)\end{array}$ & $\begin{array}{c}0.76 \\
(0.97)\end{array}$ & $\begin{array}{c}0.94 \\
(1.16)\end{array}$ & \begin{tabular}{|l|}
14 \\
$(23$ \\
\end{tabular} & \begin{tabular}{|c|}
78 \\
$(132)$
\end{tabular} & $\begin{array}{c}0.44 \\
(0.89)\end{array}$ & $\begin{array}{c}0.97 \\
(1.46)\end{array}$ & & & & & & & & \\
\hline 220 & $\begin{array}{c}21 \\
(23)\end{array}$ & $\begin{array}{c}126 \\
(138)\end{array}$ & $\begin{array}{c}0.80 \\
(0.94)\end{array}$ & $\begin{array}{c}0.99 \\
(1.15)\end{array}$ & $\begin{array}{c}13 \\
(22\end{array}$ & $\begin{array}{c}72 \\
(126)\end{array}$ & \begin{tabular}{|c|}
0.43 \\
$(0.87)$
\end{tabular} & $\begin{array}{c}0.99 \\
(1.47)\end{array}$ & & & & & & & & \\
\hline 230 & $\begin{array}{c}20 \\
(23)\end{array}$ & $\begin{array}{c}120 \\
(138)\end{array}$ & \begin{tabular}{|c|}
0.77 \\
$(0.99)$
\end{tabular} & \begin{tabular}{|c|}
0.97 \\
$(1.21)$
\end{tabular} & \begin{tabular}{|c}
11 \\
$(21)$ \\
\end{tabular} & $\begin{array}{c}60 \\
(120)\end{array}$ & \begin{tabular}{|c|}
0.38 \\
$(0.84)$ \\
\end{tabular} & \begin{tabular}{|c}
0.99 \\
$(1.49)$
\end{tabular} & & & & & & & & \\
\hline
\end{tabular}




\section{CONCLUSION}

There is a difference between theoretical computations and practical determination of ideal bubbler heights to maintain equal discharge from all bubblers. Forming mathematical program using main and minor head losses can help to determine the optimum lateral length and bubblers height. Furthermore, the program helps to use different operational conditions such as required bubbler discharges, the lateral upstream pressure allowable head $H_{a l}$, effects of water temperature $T_{w}$ bubbler diameters, lateral diameter, and soil surface slope. The program is facilitated to do the accurate and fast design calculations to have full irrigation uniformity with very low operating pressure. Low head bubbler irrigation design example was presented by using the developed program to estimate the optimal bubbler heights which give full water application uniformity. Bubbler tube diameters of 3.8, 6.0, 10.0 and $13.6 \mathrm{~mm}$ were examined with different bubbler discharges in this example.

The results showed that, the bubbler diameter and discharge had the main effect on bubbler numbers. Furthermore, the allowable pressure head $H_{a l}$ is had a great influence on small diameters (3.8 and 6.0mm); meanwhile, it had a slight effect on bubbler diameters 10.0 and $13.6 \mathrm{~mm}$.

In case of 10.0 and $13.6 \mathrm{~mm}$ diameters, when the maximum limit of bubbler height $h_{h(\max )}$ exceeds $1 m$, the bubbler number was increased, whereas it had a slight effect on small diameters 3.8 and $6.0 \mathrm{~mm}$. The friction losses are the main factor in low head bubbler design calculations. The friction losses in bubbler tube and lateral pipe are directly proportional with the $Q^{2}$ and inversely proportional with $D^{5}$. This explains the direction of the data with different discharges and bubbler sizes, where larger quantities of water discharged from small bubbler diameter 
are increasing friction loss too much. The results showed that some required discharges for small bubbler diameters are unworkable at the upstream pressure allowable head $H_{a l}$. From the opposite side the large bubbler sizes would be uneconomical when the quantity of water discharged is Low.

Laboratory experiments for evaluating the relation between the effective pressure head, $h_{e f}$ and discharge of the bubbler sizes in the design example. The discharge equations were determined to bubbler diameter with R-squared value was above 0.95. The correlation between the theoretical and practical Lateral Hydraulic Grade Line $H G L$ was high with R-squared value was above 0.99. This is empirical evidence on the accuracy of the developed program for low head bubbler design.

\section{REFERENCES}

ASABE EP 405.1 Standards (2008): Design and Installation of micro irrigation systems. St Joseph, Michigan, ASAE. 942- 945.

Bisconer, I. (2010): Why Field Crop Growers Love Drip Irrigation: Alfalfa, Corn, Cotton, Onions, Potatoes and Processing Tomatoes. ASABE Annual International Meeting, David L. Lawrence Convention Center, Pittsburgh, Pennsylvania.31pp, Paper Number: 1008764.

Boor, B., J. Kunstatsky and C. Patocka. (1968): Hydraulika Provodohospodarske stavby book, SNTL, Praha, 516 pp. M.S.M. Amin and Z.J. Svehlik1, Hydraulic Analysis of Micro-irrigation Laterals: a New Approach, Pertanika J. Sci. \& Techno!' 2(1): 107119 (1994).

Carr, M. and M. G. Kay (1980): Bubbler irrigation. Horticultural industry Journal. No. March: 11-12, Record Number 19802406454. 
Didan, K., Reynolds, C. and Yitayew, M. (1996): Bubbler Users Manual: A Computer Program for Designing Low-Head Gravity Flow Bubbler Irrigation System for Trees, Vines, and Orchard Crops. Technical Bulletin 268, Agricultural Experiment Station, College of Agriculture, The University of Arizona, Tucson, Arizona 85721.

Hashem, A. A.; Rashad, M. A.; Ramadan, M. H. and Abd El-Hak, S. M. (2011): Performance Evaluation of Low Head Bubbler Irrigation System. Journal of Soil Sciences and Agriculture Engineering, Mansoura University, Vol. 9 (2).

Hills, J. D. and Yitayew, M. (2007): chapter 14. Bubbler Irrigation, Microirrigation for Crop Production book. F.R. Lamm, J.E. Ayars and F.S. Nakayama (Editors), (C) Elsevier B.V., 553-573.

Hull, P.J. (1981): A low pressure irrigation system for orchard tree and plantation Crops. The agricultural Engineer. 55-58.

Omara, A. I., Sourell, H., Irps H., and Sommer, C. (2004): Low-pressure irrigation system powered by wind energy. Journal of Applied Irrigation Science. Vol. 39 (1): 83 - 91, ISSN 0049-8602.

Rawlins, S. L. (1977): Uniform irrigation with a low head bubbler system. Agriculture and Water Management. Elsevier Co, Amsterdam, the Netherlands. Vol 1:167-178.

Watters, G. Z. and J. Keller (1978): Trickle irrigation tubing hydraulics, ASAE Technical paper No. 78-2015. St. Joseph, Michigan.17p.

Yitayew , M.; Didan, K. and Reynolds, C. (1999): Microcomputer based low-head gravity-flow bubbler irrigation system design. Computers and Electronics in Agriculture, 22 (1999) 29-39. 


\section{الملخص العربى}

\section{تطوير برنامج لتصميم الإرتفاعات المثلى لفوار الري منذفض الضاغط}

\section{محمد أبوزيد رشاد*}

مع تزايد الحاجة لزيادة كفاءة استهلاك المياه و الطاقة تبرز اهمية نشر نظم الري ذايه ذات الكفاءة

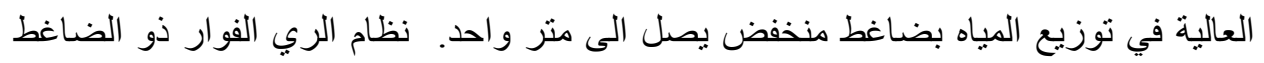

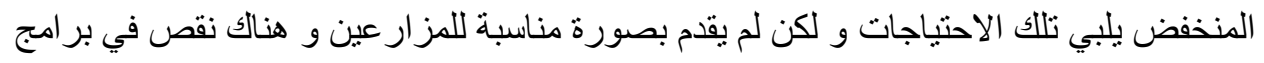
التصميم لهذه المنظومة. لذلك يهدف هذا البحث لتطوير برنامج تصميمي يعمل علي انتظامية

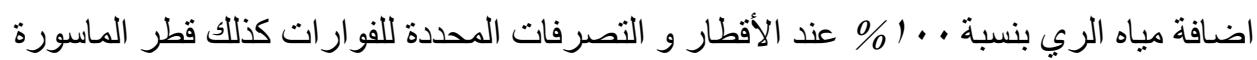

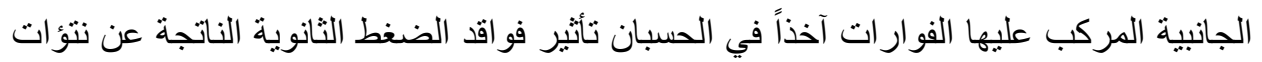

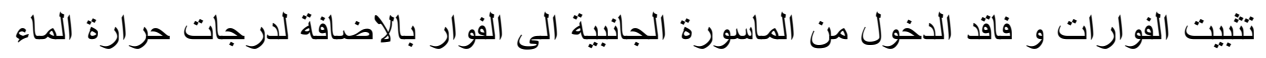

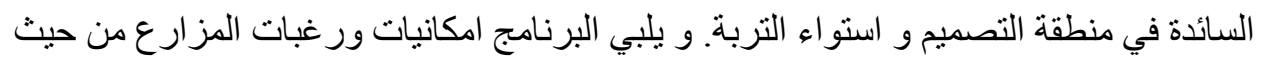

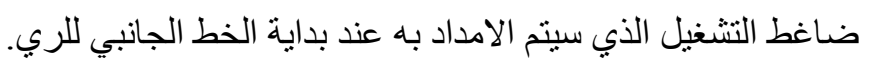

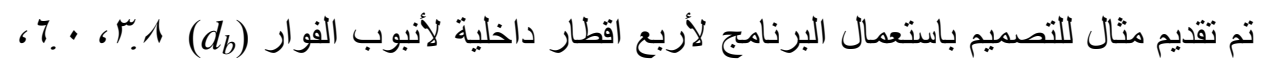

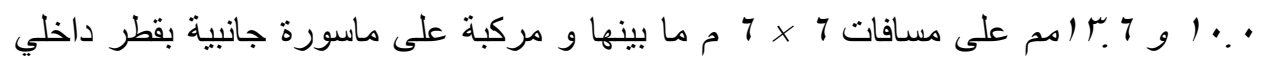

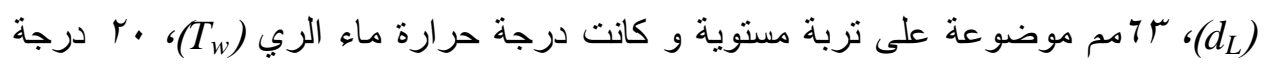

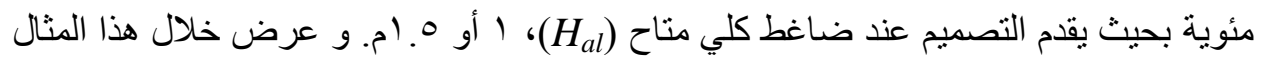
ملخص لأهم النتائج من حيث اقصى عدد لنقاط خروج الفو الفوار من الماسورة الجانبية حيث أنه أنه

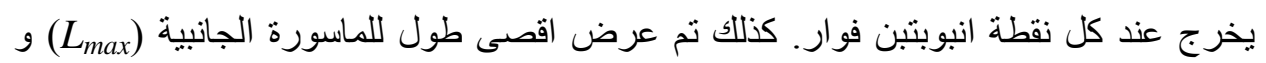
أقصى ارتفاع للفوار (

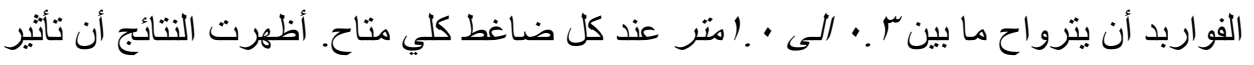

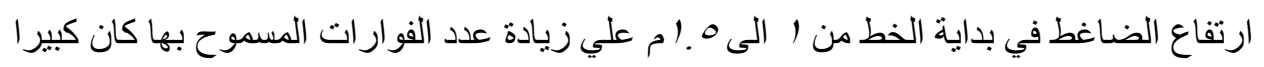

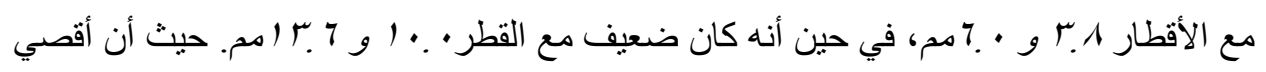

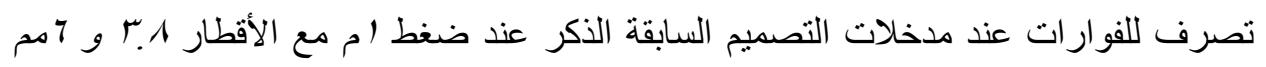

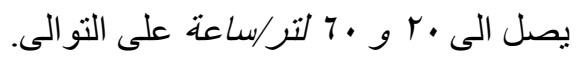

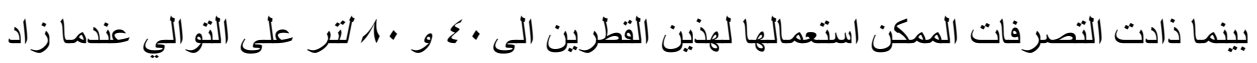

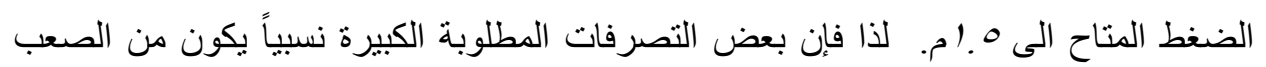

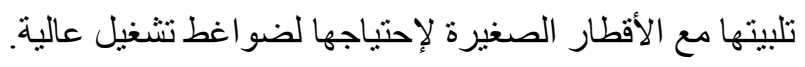

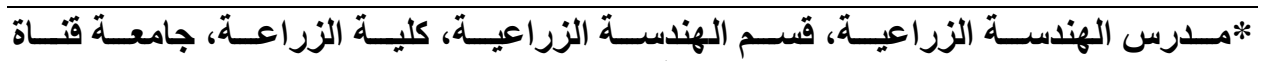

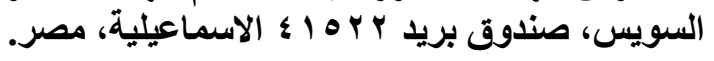


و وجد أنه في حالة زيادة الحد المسموح به لأقصى ارتفاع للفوارات عن ام تكون الزيادة في

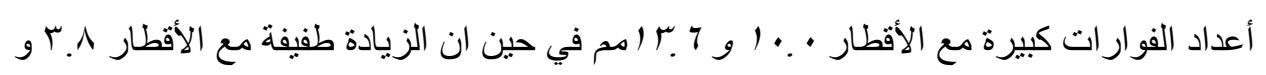

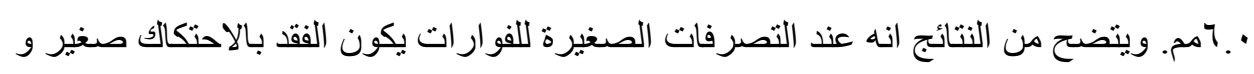

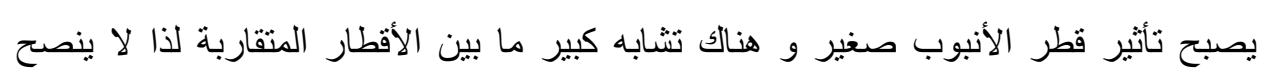

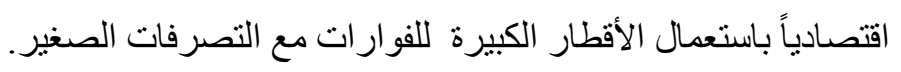

و قد تم عمل اختبار ات معملية لمدى دقة برنامج التصميم المطور و في هذا الاختبار تم قياس

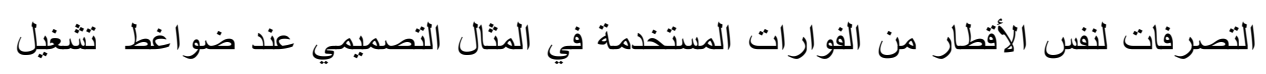

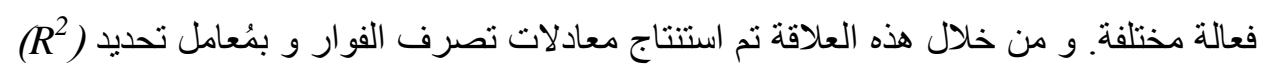

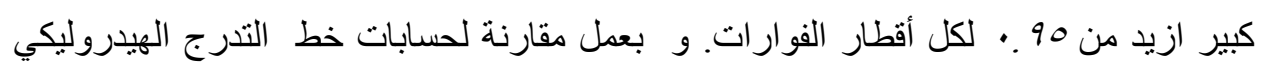

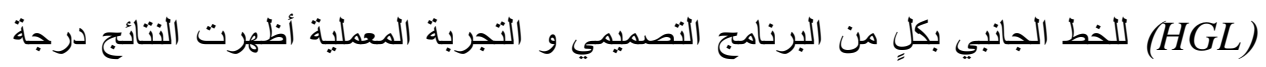

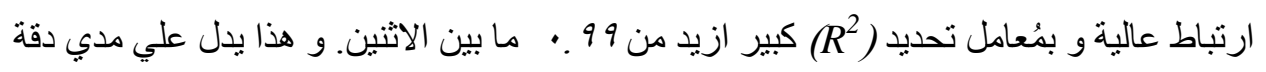

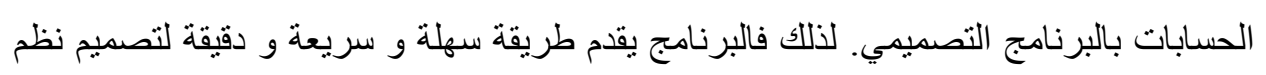

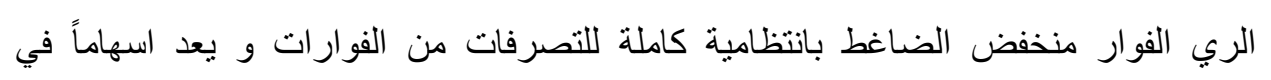
المساعدة على انتشار هذا النظام للري. 